\title{
PENGARUH INTERAKSI HARGA DAN DESAIN ATAU MOTIF BATIK TERHADAP KEPUTUSAN PEMBELIAN BATIK
}

\author{
Purwati Ratna Wahyuni ${ }^{1) *}$, Dody Tri Kurniawan ${ }^{2)}$ \\ Dosen Fakultas Pertanian Universitas Wiraraja \\ email : purwatiratna1@gmail.com dan dodytri@wiraraja.ac.id
}

\begin{abstract}
ABSTRAK
Keputusan konsumen sangat mempengaruhi hubungan antara harga dengan keputusan pembelian, di mana semakin mahal atau tinggi suatu harga maka keputusan pembelian semakin sedikit, sebaliknya jika harga murah atau rendah keputusan pembelian berubah semakin tinggi. Selain harga, terdapat faktor lain yang juga berpengaruh dalam keputusan pembelian yakni desain atau motif produk. Desain atau motif dari suatu produk merupakan salah satu faktor yang harus diperhatikan secara serius dari manajemen khususnya team pengembangan produk baru, karena tidak sedikit konsumen yang mempermasalahkan desain atau motif dari suatu produk yang mampu memenuhi kebutuhan dan keinginan konsumen. Penelitian ini bertujuan untuk menganalisis pengaruh harga terhadap keputusan membeli konsumen batik, menganalisis pengaruh desain produk terhadap keputusan membeli konsumen batik dan menganalisis pengaruh bersama harga dan desain produk terhadap keputusan membeli konsumen batik di Kabupaten Sumenep. Tujuan ini diharapkan nanti akan ditemukannya sejauh mana variable tersebut mempengaruhi penjualan atau minat beli konsumen. Analysis of variance merupakan metode untuk menguji hubungan antara satu variabel dependen (skala metrik) dengan satu atau lebih variabel independen (skala nonmetrik dengan level lebih dari dua). Hubungan antara satu variabel dependen metric dan dua variabel independen nominal sering disebut dengan Two Ways Anova. ANOVA digunakan untuk mengetahui pengaruh utama (main effect) dan pengaruh interaksi (interaction effect) dari variabel independen nominal (sering disebut faktor) terhadap variabel dependen metrik.
\end{abstract}

Kata Kunci : konsumen, Pengaruh desain dan Pengaruh harga

\section{PENDAHULUAN}

Di Indonesia dunia usah atau bisnis sangat banyak, hal ini disebabkan oleh beberapa kebijakan ekonomi yang diputuskan oleh pemerintah. Persainagn bisnis semakin ketat akibat adanya pasar bebas. Dengan demikian, perusahaan yang tidak memiliki kemampuan untuk bersaing secara otomatis akan mengalami kehancuran dengan sendirinya. Perusahaan akan sukses untuk bersaing ketika perusahaan tersebut bisa mempertahankan pelanggan. Untuk mencapai tujuan yang diinginkan, maka perusahaan hendaknya menciptakan sebuah strategi agar tujuan sesuai dengan rencana.

Dalam mengambil keputusan untuk membeli konsumen mempunyai pandangan atau persepsi yang fokus pada price, product, promotion, place (marketing mix) yang telah diterapkan oleh perusahaan selama ini. Biasanya konsumen tertarik untuk membeli ketika harga dan deain batiknya cocok. Desain yang bagus dengan harga yang terjangkau atau relative murah cenderung menjadi pilihan pertama bagi konsumen.

Hubungan antara harga dengan 
keputusan pembelian yaitu harga mempengaruhi keputusan konsumen dalam melakukan pembelian, semakin tinggi harga maka keputusan pembelian semakin rendah, sebaliknya jika harga rendah keputusan pembelian berubah semakin tinggi. Untuk itu, para pengusaha harus teliti dalam menentukan harga agar produknya bisa sukses terjual di pasar. Selain harga, faktor lain yang berpengaruh dalam keputusan pembelian adalah desain produk. Desain atau motif produk merupakan suatu faktor yang harus lebih diperhatikan oleh manajemen khususnya

\section{KAJIAN TEORITiS}

\section{Perilaku Konsumen}

Suatu kegiatan perseorangan

yang terlibat langsung dalam penggunaan suatu barang atau jasa disebut dengan perilaku konsumen, rmasuk di dalamnya proses pengambilan keputusan pada implementasi dari kegiatan tersebut (Basu Swastha,2005). Perilaku konsumen akan menentukan proses pengambilan keputusan dalam pembelian mereka. Proses pengambilan keputusan tersebut adalah solusi dalam menyelesaikan masalah dengan bebrapa tahapan. Namun, proses tersebut tidak harus dilakukan oleh konsumen dalam melakukan pembelian. Biasanya konsumen akan mengambil keputusan dalam pembelian ulang atau melakukan pembelian secara berulang-ulang dengan produk yang sama. ( Kotler, 2005 ).

Intensitas pelanggan akan meningkat secara otomatis, ketika pelanggan tersebut sudah merasa puas (Assael, 1995). Dengan adanya tingkat kepuasan dari pelanggan, maka akan tercipta kepercayaan dan loyalitas dari pelanggan tersebut.

\section{Harga}

Salah satu bauran pemasaran team pengembangan produk baru, karena sasaran konsumen yang dituju selalu mempermasalahkan desain atau motif yang bisa memenuhi kebutuhan dan keinginan konsumen.

Berdasarkan pertimbangan di atas, maka diperlukan pengkajian terhadap Pengaruh Interaksi Harga dan Desain Produk Terhadap Keputusan Pembelian Batik di Kabupaten Sumenep. Hal ini dilakukan agar dapat memperoleh acuan untuk menentukan langkah strategis sebagai usaha nyata untuk mengembangkan usahanya.

yang menghasilkan pendapatan dan merupakan salah satu unsure biaya disebut dengan harga (Kotler (2005) . Hal ini juga dibenarkan oleh Ma'ruf, menurut Ma'ruf, (2005:155) harga adalah satu-satunya unsur dalam berbagai unsur bauran pemasaran yang akan mendatangkan laba bagi peritel, sedangkan unsur-unsur yang lainnya menghabiskan biaya. Jadi, tidak dapat dipungkiri bahwasannya harga tersebut tidak berpengaruh kecil pada pendapatan dan laba bersih suatu perusahaan.

Unsure bauran pemasaran sendiri yang mudah untuk disesuaikan adalah harga, ciri-ciri produk, saluran distribusi, bahkan promosi membutuhkan lebih banyak waktu. Harga juga mengkomunikasikan posisi nilai yang dimaksudkan perusahaan tersebut kepada pasar tentang produk dan mereknya. Untuk itu, haraga merupakan salah satu cara bagi pengusaha untuk dijadikan alat pembeda penawaran dengan pesaingnya. Sehingga harga yang sudah ditetapkan dapat dipertimbangkan kembali dalam pemasaran. Biasanya penjual memiliki tujuan tertentu dalam menentukan harga jual produk. 


\section{Desain Produk}

Desain atau motif produk merupakan salah satu aspek pembentuk citra produk. Semaikin memperhatikan desain dan tampilan produk, (Stanton (1995). Dua faktor yang menyangkut desain produk adalah warna dan kualitas produk. ( Stanton, 1995 ). Pemilihan warna yang tepat merupakan keuntungan tersendiri bagi pemasaran suatu produk. Ketepatan manajemen dalam memilih warna apa yang sesuai serta kapan harus mengganti warna produk. Untuk itu, jika perusahaan mampu memilih warna produk dengan maksimal, maka perusahaan tersebut akan meraih untung yang besar. Telah lama diakui bahwa penggunaan warna yang tepat dapat meningkatkan penjualan suatu produk. Begitu pula halnya dengan mempromosikan brand secara tepat citra kualitas produk yang sesuai dengan kebutuhan dan selera konsumen. Tentunya tenga penasaran harus mampu membuat keputusan terkait dengan peningkatan kualitas produk. Seperti suatu produk harus mampu mencapai tingkat kualitas yang sesuai dengan fungsi penggunaannya.

Desain atau motif produk merupakan salah satu aspek penting yang bisa membuat konsumen tertarik. Desain atau motif tersebut sangat mendukung atribut produk sehingga produk yang dimiliki mempunyai karakter yang berbeda dari produk yang lain. (Kotler dan Amstrong,2001). Penyederhanaan ataupun peningkatan kualitas produk merupakan salah satu cara penerapan desain atau motif produk. Peningkatan desain produk dapat berupa peningkatan kualitas atau mutu serta peningkatan nilai guna dari produk tersebut. Sedangkan penyederhanaan desain atau motif produk bertujuan agar pemakaian suatu produk menjadi semakin mudah.

\section{Kerangka Konseptual}

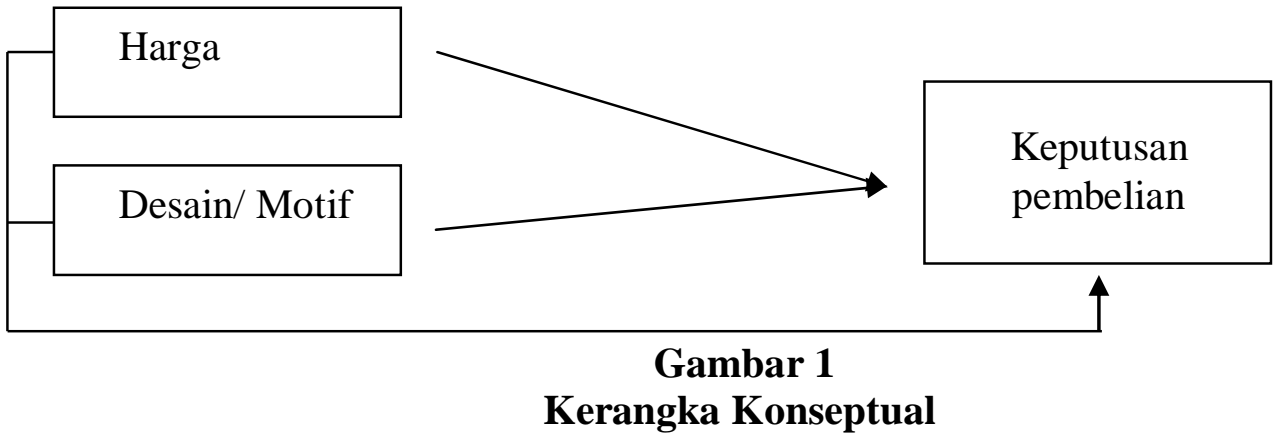

\section{METODOLOGI PENELITIAN}

\section{Populasi dan Sampel}

Populasi dalam penelitian ini adalah konsumen produk batik tulis " UD. Al-Barokah Pakandangan Kabupaten Sumenep. Konsumen mayoritas adalah dari konsumen lokal atau Kabupaten Sumenep. Unit analisis dalam penelitian ini adalah Batik Tulis UD. Al-Barokah, dimana total penjualan pada tahun 2016 sebanyak 3.548. Dengan demikian populasi di ambil dari total penjualan pada tahun 2016, maka besarnya populasi dalam penelitian ini sebesar 3.548.

Dalam penelitian ini peneliti 
mengambil anggota sampel dari populasi dengan menggunakan rumus :

$$
\begin{aligned}
& \qquad \mathrm{n}=\frac{\mathrm{N}}{1+\mathrm{Ne}^{2}} \\
& \text { Keterangan : } \\
& \mathrm{n} \quad=\text { Jumlah sampel } \\
& \mathrm{N} \quad=\text { Jumlah populasi } \\
& \mathrm{e} \quad=\text { Batas kesalahan yang di } \\
& \text { toleransi }(1 \%, 5 \%, 10 \%) \\
& \text { Maka : } \\
& \qquad \mathrm{n}=\frac{3.548}{1+3.548 .10 \%^{2}} \\
& \mathrm{n}=97,2 / 100
\end{aligned}
$$

\section{Pengujian Hipotesis}

Untuk melihat signifikasi faktor harga dan desain produk yang berpengaruh terhadap keputusan konsumen untuk membeli perlu dilakukan uji signifikansi. Di mana Uji signifikansi memerlukan perumusan Ho dan Ha. serta pengaruh interaksi harga dan desain produk terhadap keputusan membeli konsumen batik dengan menggunakan uji F. Analisis varian dalam penelitian ini akan dilakukan dengan bantuan alat statistic SPSS.
Hipotesis yang ditentukan dalam penelitian ini adalah sebagai berikut:

Ho : Tidak ada pengaruh harga terhadap keputusan membeli

H1 : Ada pengaruh harga terhadap keputusan membeli

Ho : Tidak ada pengaruh desain produk terhadap keputusan membeli

H2 : Ada pengaruh desain produk terhadap keputusan membeli

Ho : Tidak ada pengaruh bersama harga dan desain produk terhadap keputusan Membeli

H3 : Ada pengaruh bersama harga dan desain produk terhadap keputusan membeli

\section{PEMBAHASAN \\ Deskriptif Variabel Penelitian Variabel Harga}

Pada variabel deskriptif harga, penilaian dilakukan dengan 3 indikator, diantaranya adalah keterjangkauan harga, daya saing harga, dan kesesuain harga dengan manfaat, berikut adalah tabel 1 tentang deskriptif harga.

Tabel 1. Deskriptif Variabel Harga

\begin{tabular}{|c|l|l|l|}
\hline No & \multicolumn{1}{|c|}{ Kriteria } & Frekuensi & Persentase \\
\hline 1 & Sangat Setuju & 34 & $34 \%$ \\
\hline 2 & Setuju & 53 & $53 \%$ \\
\hline 3 & Kurang Setuju & 11 & $11 \%$ \\
\hline 4 & Tidak Setuju & 2 & $2 \%$ \\
\hline 5 & Sangat Tidak Setuju & - & - \\
\hline \multicolumn{2}{|c|}{ Jumlah } & 100 & $100,0 \%$ \\
\hline
\end{tabular}

Sumber : Data primer diolah 2018

Berdasarkan tabel 1 di atas dapat diketahui dari 100 responden ternyata sebagian besar yaitu 53 responden (53\%) menyatakan setuju bahwa harga Batik Tulis UD. Al-Barokah tergolong baik, sebanyak 34 responden (34\%) menyatakan sangat setuju bahwa harga Batik Tulis UD. AL-Barokah tergolong baik, dan 11 responden (11\%) yang menyatakan kurang setuju, serta hanya 2 responden $(2 \%)$ yang menyatakan tidak setuju. Hal ini berarti bahwa persepsi responden pada harga Batik Tulis UD. Al-Barokah tergolong baik atau sesuai dengan harapan konsumen. 


\section{Variabel Desain Produk}

Pada variabel deskriptif inovasi produk, penilaian dilakukan dengan 5 indikator, diantaranya adalah daya tarik tampilan, variatif dalam ukuran, variatif dalam motif, variatif dalam warna, dan inovatif, berikut adalah tabel deskriptif desain produk

Tabel 2. Deskriptif Variabel Desain Produk

\begin{tabular}{|c|l|l|l|}
\hline No & Kriteria & Frekuensi & Persentase \\
\hline 1 & Sangat Setuju & 28 & $28 \%$ \\
\hline 2 & Setuju & 51 & $51 \%$ \\
\hline 3 & Kurang Setuju & 20 & $20 \%$ \\
\hline 4 & Tidak Setuju & 1 & $1 \%$ \\
\hline 5 & Sangat Tidak Setuju & - & - \\
\hline \multicolumn{2}{|c|}{ Jumlah } & 100 & $100,0 \%$ \\
\hline
\end{tabular}

Sumber : Data primer diolah 2018

Berdasarkan tabel 2. diketahui

dari 100 responden ternyata sebagian besar yaitu 51 responden (51\%) menyatakan setuju bahwa desain produk yang dilakukan Batik Tulis UD. AlBarokah tergolong baik, sebanyak 28 responden $(28 \%)$ menyatakan sangat setuju bahwa desain produk tergolong baik, dan 20 responden (20\%) yang menyatakan kurang setuju, serta hanya 1 responden $(1 \%)$ yang menyatakan tidak setuju. Hal ini berarti bahwa persepsi responden pada desain produk yang dilakukan Batik Tulis UD AL-Barokah tergolong baik sebagai produk yang diterima konsumen sesuai selera.

\section{Variabel Keputusan Pembelian}

Pada variabel deskriptif keputusan, penilaian dilakukan dengan 3 indikator, diantaranya adalah dorongan dari dalam diri, motif sosial, dan motif emosional, berikut adalah tabel deskriptif keputusan pembelian.

Tabel 3. Deskriptif Variabel Keputusan Pembelian

\begin{tabular}{|c|l|l|l|}
\hline No & \multicolumn{1}{|c|}{ Kriteria } & Frekuensi & Persentase \\
\hline 1 & Sangat Setuju & 32 & $32 \%$ \\
\hline 2 & Setuju & 56 & $56 \%$ \\
\hline 3 & Kurang Setuju & 12 & $12 \%$ \\
\hline 4 & Tidak Setuju & - & - \\
\hline 5 & Sangat Tidak Setuju & - & - \\
\hline \multicolumn{2}{|l|}{ Jumlah } & 100 & $100,0 \%$ \\
\hline
\end{tabular}

Sumber : Data primer diolah 2018

Berdasarkan tabel 3. di atas dapat diketahui dari 100 responden ternyata sebagian besar yaitu 56 responden $(56 \%)$ menunjukkan setuju bahwa keputusan pembelian terhadap Batik Tulis UD. Al-Barokah tergolong tinggi, sebanyak 32 responden (32\%) menunjukkan sangat setuju bahwa keputusan pembelian terhadap produk ini tergolong tinggi, dan 12 responden
(12\%) menunjukkan kurang setuju. Hal ini berarti bahwa keputusan pembelian terhadap produk Batik Tulis UD. AlBarokah tergolong tinggi sesuai keinginan, kebutuhan dan kemampuan konsumen.

\section{Analisis Regresi Berganda}

Berdasarkan analisis dengan program SPSS 17 for Windows diperoleh hasil regresi berganda seperti terangkum 
pada tabel berikut:

Tabel 4. Hasil Analisis Regresi Berganda

\section{Coefficient $\mathrm{s}^{\mathrm{a}}$}

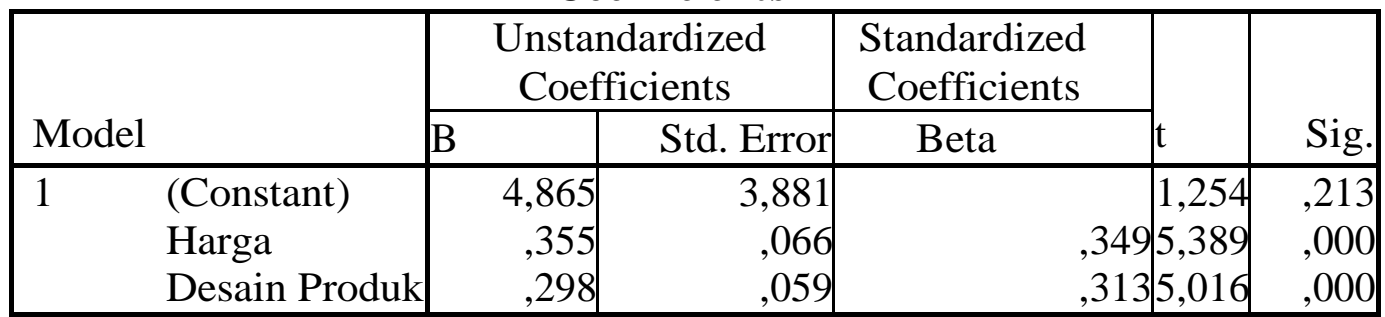

a. Dependent Variable: Keputusan Pembelian

Sumber : Data primer diolah, 2018

Berdasarkan tabel di atas diperoleh persamaan regresi berganda sebagai berikut:

\section{$Y=4,865+0,355 X_{1}+0,298 X_{2}$}

Persamaan regresi tersebut mempunyai makna sebagai berikut:

a. Konstanta $=\mathbf{4 , 8 6 5}$

Jika variabel harga dan desain produk dianggap sama dengan nol, maka variabel keputusan pembelian sebesar $\mathbf{4 , 8 6 5}$.

b. Koefisien Harga $\left(\mathrm{X}_{1}\right)=\mathbf{0 , 3 5 5}$ Jika variabel harga mengalami kenaikan, sementara desain produk diasumsikan tetap, maka keputusan pembelian akan meningkat sebesar $\mathbf{0 , 3 5 5}$.

c. Koefisien Desain Produk $\left(\mathrm{X}_{2}\right)=$ $\mathbf{0 , 2 9 8}$

Jika variabel desain produk mengalami kenaikan, sementara harga

Tabel 5. Hasil Uji t

Coefficient $\mathbf{s}^{\mathrm{t}}$

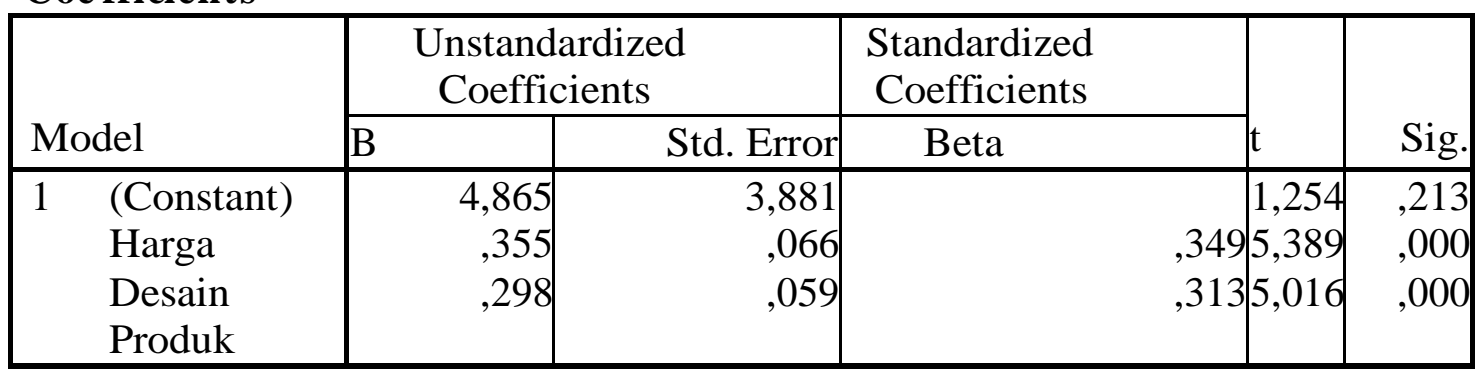

a. Dependent Variable: Keputusan Pembelian

Sumber : Data primer diolah, 2018 
Berdasarkan hasil pengujian yang telah dilakukan, diperoleh nilai:

a. thitung untuk variabel harga

sebesar 5,389 dengan signifikansi $0,000<0,05$.

Dari hasil tersebut dapat diketahui bahwa pengujian tersebut menolak Ho dan menerima $\mathrm{H}_{1}$ yang menyatakan ada pengaruh positif dan signifikan harga terhadap keputusan pembelian diterima.

b. $t_{\text {hitung }}$ untuk variabel desain produk sebesar 5,016 dengan signifikansi $0,000<0,05$. Dari Tabel 6. Hasil Uji F hasil tersebut dapat diketahui bahwa pengujian tersebut menolak $\mathrm{Ho}$ dan menerima $\mathrm{H}_{1}$ yang menyatakan ada pengaruh positif dan signifikan desain produk terhadap keputusan pembelian diterima..

\section{Secara Simultan (Uji F)}

Uji $F$ dilakukan untuk melihat keberartian pengaruh variabel independen secara simultan terhadap variabel dependen atau sering disebut uji kelinieran persamaan regresi. Untuk melakukan uji $\mathrm{F}$ dapat dilihat pada tabel anova di bawah ini:

ANOV A ${ }^{b}$

\begin{tabular}{|ll|r|r|r|l|l|}
\hline \multirow{2}{*}{ Model } & \multicolumn{1}{|l|}{$\begin{array}{c}\text { Sum of } \\
\text { Squares }\end{array}$} & df & $\begin{array}{r}\text { Mean F } \\
\text { Square }\end{array}$ & Sig. \\
\hline 1 & Regression & 9360,323 & 3 & 3120,108 & 127,619 &, $000^{\mathrm{a}}$ \\
& Residual & 2664,898 & 109 & 24,449 & & \\
\hline & Total & 12025,221 & 112 & & & \\
\hline
\end{tabular}

a. Predictors: (Constant), Harga, Desain Produk

b. Dependent Variable: Keputusan Pembelian

Sumber : Data primer diolah, 2018

Pada tabel Anova diperoleh nilai

$\mathrm{F}_{\text {hitung }}=127,619>\mathrm{F}_{\text {tabel }}=2,70$ dan sig $=0,000<0,05$ ini berarti variabel independen harga dan desain produk secara simultan benar-benar berpengaruh signifikan terhadap variabel dependen keputusan pembelian. Maka dengan kata lain variabel-variabel independen harga dan desain produk mampu menjelaskan besarnya variabel dependen keputusan pembelian.

Koefisien Determinasi Ganda (R2)

Untuk melihat besarnya pengaruh variabel independen terhadap variabel dependen secara keseluruhan dapat dilihat pada tabel model summary berikut ini:

Tabel 7. Koefisien Determinasi Ganda

Model Summary

\begin{tabular}{|l|r|r|r|r|}
\hline Model & R & R Square & $\begin{array}{r}\text { Adjusted } \\
\text { R Square }\end{array}$ & $\begin{array}{c}\text { Std. Error of the } \\
\text { Estimate }\end{array}$ \\
\hline 1 &, $882^{\mathrm{a}}$ &, 778 &, 772 & 4,9446 \\
\hline
\end{tabular}

a. Predictors: (Constant), Harga dan Desain Produk 
b. Dependent Variable: Keputusan Pembelian

Sumber : Data primer diolah, 2018

Pada tabel 7. di atas diperoleh nilai Adjusted $\mathrm{R}^{2}=0,772=77,2 \%$ ini berarti variabel bebas harga dan desain produk secara bersama-sama mempengaruhi variabel dependen keputusan pembelian sebesar 77,2\% dan sisanya dipengaruhi oleh variabel lain yang tidak masuk dalam penelitian ini.

\section{Koefisien Determinasi Parsial (r2)}

perlu

Selain melakukan uji $t$ maka

Tabel 8. Koefisien Determinasi Parsial

Coefficient $\mathbf{s}^{\mathrm{a}}$

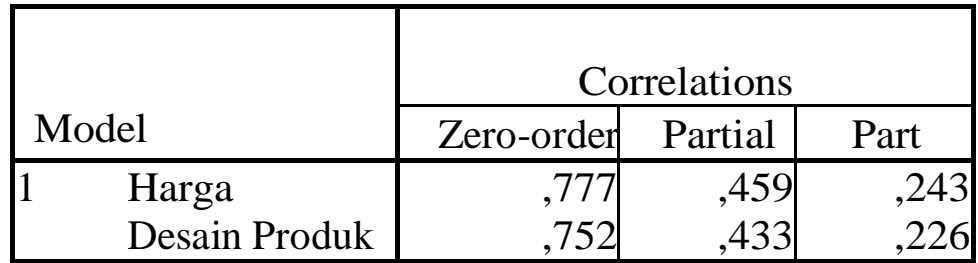

a. Dependent Variable: Keputusan Pembelian

Sumber : Data primer diolah, 2018 juga mencari besarnya koefisien determinasi parsialnya untuk masingmasing variabel bebas. Uji determinasi parsial ini digunakan untuk mengetahui seberapa besar sumbangan dari masingmasing variabel bebas terhadap variabel terikat.

Secara parsial kontribusi harga dan desain produk terhadap kepuasan konsumen bisa dilihat pada tabel berikut ini:
Berdasarkan tabel 4.16. diketahui besarnya $r^{2}$ harga yang diperoleh dari koefisien korelasi parsial untuk variabel harga yang diperoleh dari koefisien korelasi parsial untuk variabel harga dikuadratkan yaitu $(0,495)^{2}=0,2109 \mathrm{x}$ $100 \%=21,09 \%$. Besarnya pengaruh desain produk yang diperoleh dari koefisien korelasi parsial untuk variabel desain produk dikuadratkan yaitu $(0,433)^{2}=0,1875 \times 100 \%=18,75 \%$. Hal ini menunjukkan bahwa variabel harga memberikan pengaruh lebih besar terhadap keputusan pembelian dibandingkan desain produk.

\section{KESIMPULAN DAN SARAN}

\section{Kesimpulan}

Kesimpulan yang dapat diambil dari penelitian ini adalah sebagai berikut:

1. Terbukti bahwa harga berpengaruh positif dan signifikan terhadap keputusan pembelian Batik Tulis UD. Al-Barokah. Artinya semakin tinggi atau baik pandangan tentang harga yang ditawarkan berakibat pada semakin tinggi keputusan pembelian.

2. Terbukti bahwa desain produk berpengaruh positif dan signifikan terhadap keputusan pembelian Batik Tulis UD. Al-Barokah. Artinya semakin baik dan variatif desain batik yang dilakukan berakibat pada semakin tinggi keputusan pembelian.

3. Terbukti bahwa harga dan desain produk berpengaruh secara simultan dan signifikan terhadap keputusan pembelian Batik Tulis UD. AlBarokah.

\section{Saran}

Saran yang dapat diambil dari 
penelitian ini adalah sebagai berikut :

1. Hasil penelitian menunjukkan bahwa indikator dari variabel desain produk yang mempunyai pengaruh paling lemah terhadap keputusan pembelian, maka perlu adanya pengembangan inovasi desain dan motif dari produk seperti perpaduan kalsik dan modern.

2. Bagi peneliti selanjutnya dapat melakukan penelitian pada subyek yang berbeda dengan membatasi subyek yang membeli produk tersebut baru satu kali atau hanya satu kali dan tidak hanya melihat dari sudut pandang dari konsumen atau pengunjung saja, akan tetapi juga sudut pandang dari pihak produsen.

\section{DAFTAR PUSTAKA}

Abdullah, Thamrin dan Francis Tantri. (2012). Manajemen Pemasaran. Jakarta: PT. Grafindo Persada.

Bungin, Burhan. (2011). Metodologi Penelitian Kuantitatif. Jakarta: Kencana Prenada Media

Daryanto. (2011). Sari Kuliah Manajemen Pemasaran. Bandung: PT. Satu Nusa.

Ginting, Nembah F. Hartimbul. (2011). Manajemen Pemasaran. Bandung: CV. Yrama Widya.

Hasan et al. (2010). "Teori dan Model Perilaku Konsumen". Makalah Fakultas Ilmu Sosial dan Ilmu Politik Universitas Wijaya Kusuma Surabaya.

Kotler, Philip. (1992). Manajemen Pemasaran: Analisis, Perencanaan, Implementasi, dan Pengendalian, (Edisi Keenam, Jilid 2). Jakarta: Erlangga.
Kotler, Philip dan Keller Kevin Lane. (2009). Manajemen Pemasaran, (Edisi Ketiga Belas, Jilid 2). Jakarta: Erlangga.

Kotler, Philip dan Keller Kevin Lane. (2007). Manajemen Pemasaran. (Edisi Kedua Belas, Jilid 2). Jakarta: Erlangga.

Riduwan dan Engkos Ahmad Kuncoro. (2011). Cara Menggunakan dan Memaknai Analisis Jalur (Path Analysis). Bandung: Alfabeta.

Sarwono Jonathan dan Martadiredja, Tutty. (2008). Riset Bisnis untuk Pengambilan Keputusan. Yogyakarta: ANDI.

Sekaran, Uma. (2007). Metodologi Penelitian Untuk Bisnis. Jakarta: Salemba Empat.

Sugiyono. (2009). Metodologi Penelitian Kuantitatif , Kualitatif, dan R\&D. Bandung: Alfabeta.

Sunyoto, Danang. (2012). Konsep Dasar Riset Pemasaran Perilaku Konsumen. Yogyakarta: Center for Academic Publishing Service.

Taniredja, Tukiran dan Mustafidah,Hidayati. (2011).

Penelitian Kuantitatif. Bandung: Alfabeta.

Tjiptono, Fandy. (2008). Strategi Pemasaran. Yogyakarta: ANDI.

Wijaya, Toni. (2013). Metodologi Penelitian Ekonomi dan Bisnis : Teori dan Praktik. Yogyakarta: Graha Ilmu. 